\title{
GREEN BURIAL IN HONG KONG
}

\author{
Cynthia S. Y. Lau', Hilary H. L. Yee', Tommy K. C. Ng', Ben Y. F. Fong' \\ 1. School of Professional Education and Executive Development, The Hong Kong Polytechnic University, Hong Kong
}

Correspondence: cynthialau1227@gmail.com

\begin{abstract}
Green Burial is a burial method which uses biodegradable materials to entomb the dead body instead of cremating by using embalmed liquid. It aims to let the body return to the nature naturally. With an ageing population, there is an increase of demand on columbarium and niches in Hong Kong, and green burial has been introduced as a more sustainable option to bury the deceased. The current paper has summarised the official documents regarding the green burial programme proposed by the Hong Kong government. The reason why people do not prefer green burial may be due to the Chinese traditional belief and the lack of education. Methods of delivery of message and social media coverage are issues leading to people not being encouraged to use green burial. United States and Singapore develop improved approaches in performing green burial. The effect in promoting green burial services is evaluated in this study and recommendations on improving the way of promotion are proposed.
\end{abstract}

\section{KEYWORDS}

columbarium, niches, green burial, project management, scattering ashes

\section{INTRODUCTION}

In the last three decades, the situation of ageing population has become more serious. The Census and Statistics Department has stated that the percentage of elderly who are above 65 years old in the population has increased from $14.2 \%$ in 2013 to $17.0 \%$ in 2018 . The birth rate has decreased from $8.0 \%$ in 2013 to $7.2 \%$ in 2012 but the death rate has increased from $6.0 \%$ in 2013 to $6.3 \%$ in 2018 . With an ageing population in Hong Kong, the demand for niches and columbarium facilities will also be increasing, and more supply will be required. [1]

Columbarium is a place where people place the ashes of deceased. It gives a site for family members to show their respect and pray during memorial days. After the dead body is cremated, the niches or ashes are placed into an urn and sealed. The urn is then put into the public or private columbarium for praying by family members. According to the statistics estimated by the government Research Office, the average number of deaths will increase from around 45,000 in 2018 to 72,500 in 2037 while the number of cremations will also increase from 42,000 in 2018 to 68,000 in 2037. Although the government has opened three new public columbarium facilities during 2012 to 2014 and regulated private columbaria licenses, the supply of niches remains a concern. [2] Therefore, the government has started to promote green burial, a sustainable and ecofriendly method to deal with the ashes of the dead. People can scatter the ashes at 12 Gardens of Remembrance (GoR) operated by Food and Environmental Hygiene Department (FEHD) or at sea. The number of scattering ashes in GoRs and at sea has increased from 335 to 6,558 from 2007 to 2019. [3,4] However, not everyone accepts this new way of burial as it clashes with the Chinese traditional view on burying their deceased family members in a 'safe place'. It still needs time for the general public to accept it. 


\section{HISTORY AND DEVELOPMENT OF BURIAL SERVICE}

Embalming and burial service was first established in the United States during the Civil War. Many soldiers went to the war, that had caused many deaths. To preserve the deceased individuals for transportation, embalming fluid was put on their dead bodies. Hence, burial service started to develop and the first cemetery for military was built in United States. [5]

In the traditional conventional burial, bodies are buried underground inside a concrete grave liner. [6] This kind of burial contributes to environment pollution as the decomposition of dead bodies will slowly create greenhouse gas methane. Pollutants are also generated by the manufacture of embalming fluids, caskets and grave liners. This method requires a large amount of land for the cemeteries, thus destroying natural green area. Whereas another option is cremation in which the dead bodies are burnt at a very high temperature and then pulverised into ashes. During the process of cremation, carbon fuel consumption generates carbon dioxide, which is emitted into the atmosphere, causing pollution to the environment.

In order to obtain a more environmental-friendly and sustainable way to handle human dead bodies, green burial was then promoted in the early 1990's in United Kingdom. They promoted green burial in order to save lands for development as well as to protect the environment. This practice has been widespread to other countries such as United States and Canada for reference and promotion. [7]

\section{PRINCIPLES OF GREEN BURIAL}

Green Burial is a burial method which uses biodegradable materials to entomb the dead body instead of cremating by using embalmed liquid. It aims to let the body return to nature naturally. It is carried out differently around the world. Green Burial Council of the United States considers burial as 'green' as long as it cares for the dead with minimal environmental impact that helps in the conservation of natural resources, reducing carbon emissions, protecting workers health and restoring and/or preservation of natural habitat. [8]

In Western countries like the United States and Canada, green burial is also called natural burial in which the dead bodies will not be cremated with embalming liquid. They are put into a biodegradable shroud or coffin and, buried without putting the vault on the top. While in Hong Kong, due to scarce land resources, green burial is promoted as a more environmental-friendly and sustainable way of handling human ashes which are scattered either in memorial gardens or at sea.

Apart from being more environmental-friendly, green burial also aims to finish the decomposition of the whole body and let it return naturally back to the soil and the nature. [9] The decomposition of the dead body will become the local indigents of the natural plants. This can have a bigger and better local ecosystem in the internment place where the body and body ashes are buried. Besides, green burial will not place artificial memorials in the buried place. Most of them will place some memorials which are made by natural material and have a simple description. [7]

\section{GREEN BURIAL IN HONG KONG}

\section{APPLICATION PROCEDURE}

There are two types of green burial services provided in Hong Kong, including scattering the ashes at the twelve GoR or into the sea. The application of performing green burial is free of charge but descendants must obtain the "Permit to Take Away Cremated Ashes" of the deceased if they would like to scatter the human ashes.

For scattering the ashes at the GoR in the city, relatives have to submit the original of the "Permit to Take Away Cremated Ashes" to one of the Cemeteries and Crematoria Office. For the GoR in the islands, they must obtain a document issued by the respective rural committee and the statutory declaration which can prove that the deceased was a villager of the island district, i.e. a local resident who lived there for a long period of time. If the deceased is the child of parents who are the villagers of the island district, the ashes can also be scattered at the GoR in the islands. The office will return the result of permission within 5 working days (Appendix I). [10]

For the scattering the ashes at sea, the family can arrange their own vessel trip or use the free ferry service provided by the FEHD to the three designated areas for scattering. After that, they should fill in the corresponding application form for scattering of cremated human ashes and submit it to one of the Cemeteries and Crematoria Office together with the original of "Permit to Take Away Cremated Ashes". 
The office will return the result of application within 5 working days (Appendix II). [10]

\section{ADVANTAGES OF PROMOTING GREEN BURIAL IN HONG KONG}

One major advantage of promoting green burial is to avoid the construction of large piece of land to bury the dead bodies or to store funeral urns. Hong Kong is facing a huge challenge in finding places for the storage of the ashes of the dead as the current six government crematoria and eight of the nine public columbaria are nearly saturated. [11] Despite the government has promised to set up six more columbaria which can provide at least 300,000 niches to the public in the coming five years, the supply can barely meet the demand, as reflected from the waiting time of one month to 99 months for niches arrangement.

[12] In green burial, only green area in memorial gardens is required. This helps to ease the pressure of finding suitable land for building more columbarium. Hence, the government can reserve more land for urbanisation or city development.

Green burial is cost effective and can reduce carbon footprint. Although cremation is still being adopted in Hong Kong and is releasing certain amount of carbon dioxide to pollute the atmosphere, resources like copper, concrete, steel and wood for producing caskets or coffins will be saved. [10] This helps to lower additional expenses on embalming or manufacturing metal vaults for cremation and also protect the environment by producing fewer toxic gases like carbon dioxide, sulphur dioxide, dioxin and nitrogen oxide.

After scattering the ashes into the ground or sea, they will become a part of the life cycle of nature and in line with a purpose of letting the deceased to return to nature. They will act as natural ingredient to help the plant grow. Plants can receive the nutrients and the native areas are preserved.

\section{PROMOTION OF GREEN BURIAL IN HONG KONG}

FEHD has a designated website to introduce green burial to the public. A memorial website of the deceased has also been developed. The family can establish a memorial web page to pay tribute to the deceased anywhere and at any time. A mobile application version with more function keys is being developed. [2] Posters, banners and leaflets are displayed in the public transportation system, hospitals and
Cemeteries and Crematoria Office. Seminars and exhibitions are organised in conjunction with tertiary institutions and non-government organisations. Furthermore, some promotion video clips are produced and broadcast in different media.

Starting from 2019, the government has launched a trial programme with tours of scattering ashes at sea. It gives people a chance to experience and be familiarised with this service. The tours are arranged on the last Saturday of each month with application beforehand. A guide will explain the process of green burial at the sea. Moreover, people can register for having green burial when they are still alive. [13]

\section{ISSUES ON PROMOTION}

The messages of green burial are not delivered to the public effectively. A report by Legislative Council [2] has criticised the accessibility of materials in the internet and public transportation system. Despite the availability of various types of promotion activities and different kinds of promotion materials such as leaflets and booklets provided by FEHD, the publicity for green burial is still limited. People must surf on the internet when their family or relatives passed away. Other than the thematic website of green burial, details and information are hard to be accessed.

Education on green burial, as well as on life and death, for the young generation is not enough. In the education curriculum, there are no specific life and death topics or courses. Most of the young start having death education in universities and there are few universities that conduct death education courses. A study has found that university students in Hong Kong have negative feelings and strong avoidance of death before having any death education courses and they think that life and death have weak correlation. They changed their attitude to slightly positive after having completed death education courses. [14] Although the government has organised talks and exhibitions on green burial, most of them are held at housing estates, elderly centres or old age homes. This has limited to target elderly group only. The talks held in secondary schools and the set-up of one-time promotion booth at the Health Education and Resource Centre of FEHD are not effective and cannot spread the messages validly due to the short duration and difficulty to inspire young people.

Moreover, traditional Chinese belief and culture are important factors that influence the public acceptance of 
green burial. Complying with all the rules and rituals of funeral are important as proper funerary ceremonies could ensure a good transition to the afterlife for the dead. [15] People believe that the quality of afterlife of the deceased is also affected by the funerary procedures and ceremonies which demonstrate the respect and worship from family to the deceased. The next generation follow the routine to sweep the tomb and pray in the ceremony in order to make good wishes for both the deceased and family members, especially in Ching Ming Festival and Chung Yeung Festival, which are traditional Chinese festivals in spring and autumn each year respectively for family members to express their filial piety to the deceased with grave-sweeping.

Scattering ashes and sea burial are considered as disrespectful to the deceased and violating the tradition of giving a 'home' to the ancestors as they are just being randomly left all over the place. Online memorial webpage is the new way of memorial service promoted along with green burial. This is even more hard to be accepted by the general public, especially the older generation, as people pay tribute and show condolence only through the internet. The dedicated memorial webpage shows the name and date of death of the deceased and people can design the layout and set up different features for it. This has replaced the traditional worship ritual and broke the practice of the long-time Chinese tradition.

\section{PRACTICE IN OTHER COUNTRIES}

Green Burial has been popular in these few decades over the world. Some countries continue modifying their practice with new ideas.

\section{United States}

The United States uses green burial as a nature conservation tool to protect their natural places. There are 7 green burial sites across the United States and mainly located in the east and west part of the whole country. Since contemporary burial leaves much metal being disposed into the soil, green burial uses paper, banana leaf or bamboo to be the casket and without doing any embalming on the dead body. The burial places can gain more nutrients, so the government can find more open space and reserve natural habitats. It can also increase the biotic diversity to let animals and plants have better concentration. Since the area of these burial sites are large, they can provide wildife corridors and protect the ecosystems. Some areas are listed as protected meadow, protected forest and mountain heritage area. [16] This is a win-win-win situation for both human, animals and the environment.

\section{Singapore}

The National Environment Agency [17] under the Singapore government launched a new green burial method in 2007 called Crypt Burial System (CBS). It is an improved version of traditional soil burial where burial places are made by a crypt without a base and lay out in grids. This method can utilise the land more effectively and prevent graves shifting because of erosion or the soil movement. They put the ashes of deceased into a biodegradable urn and then place underground or scatter the ashes directly to the ground. People can perform it in any green burial sites approved by National Environment Agency and use different grave markers to locate the site like plants, GPS system or 3D objects.

\section{POLICY AND PRACTICE OF GREEN BURIAL - THE WAY FORWARD}

The government should evaluate the green burial policy in two to four years. Evaluation monitor and knowing the service satisfaction of the citizens are important in the development and management of a promotion project or a new policy. Research centres could be set up or universities can be engaged to conduct surveys on the usage and public preference on green burial. This facilitates the government in getting clearer views on recent utilisation, the limitations and progress by knowing how and why people choosing green burial at the last stages of their life. Then the FEHD can have a better plan to re-design the current promotion and to have a better scheme on the services of green burial.

Promotional materials such as leaflets and advertising videos should be distributed and broadcast more frequently in hospitals, day care centres and in different social media such as Instagram, YouTube, Facebook, etc. to increase publicity. Moreover, posters and banners can be displayed in relevant after-death service department to introduce an alternative option of burial. The government can also collaborate with radio broadcast or television companies to produce programmes about the detail of green burial. These actions aim to arouse the curiosity, awareness or concern on green burial in the public.

Also, the government should educate teenagers about this concept. In the secondary education syllabus, life 
education lesson can let them know about the prevention and risk of suicide. The Education Bureau can introduce a section at school about the human life cycle. It can guide students to start thinking about the meaning of life and promote the knowledge of green burial. Students can then share what they have learnt about green burial from school with their families and friends to raise their interest.

The government can provide subsidy in memorial products. Memorial diamond and crystal are popular memorial products in western counties. Yet, there are only few companies in Hong Kong provide this kind of service. The cost of this service is expensive because of the special skills in making crystal or diamond. The government can subsidise those who would like to have the memorial diamond or crystal after scattering the ashes at the GoR or at the sea. It can also help to promote green burial to the citizens.

Moreover, the government can offer more places for scattering the ashes. They are extending the areas in the present twelve GoR and building up more memorial plaques. Descendants can still have the traditional routine in Chung Yeung Festival or Ching Ming Festival and pray for the deceased in front of the plaques. This method should be emphasised more by the government as it can maintain the balance between tradition and modern practice and make it more acceptable to the public.

\section{CONCLUSION}

The demand for columbarium facilities and niches has been increasing continuously due to the ageing population and uptrend in the number of deaths. The supply of niches is under pressure and has aroused the concern about its adequacy in coming years. To ease the shortage of niches, the government has promoted a new method on the afterlife of deceased called green burial. However, it is facing obstacles in getting people to accept this alternative burial as it is a traditional practice in Hong Kong to keep body ashes of the deceased in ceramic urns and store them in columbarium niches. The government must improve the way of promoting green burial by conducting more education talks in schools and to the public and increasing promotion through social media. Then, people can gain more information and

understanding about it and encourage them to consider green burial.

\section{ACKNOWLEDGEMENT}

The work described in this paper was partially supported by a grant from the Research Grants Council of the Hong Kong Special Administrative Region, China (Project Reference No.: UGC/IDS24/18).

\section{References}

1. Census and Statistics Department. Hong Kong in Figures. [Internet]. 2019. [cited 3 November 2019]. Available from:

https://www.statistics.gov.hk/pub/B10100062019AN19B 0100.pdf

2. Legislative Council. New Allocation Arrangement for the Public Niches and Green Burial Initiatives.

[Internet]. 2018. [cited 3 November 2019]. Available from: https://www.legco.gov.hk/yrl7-

18/english/panels/fseh/papers/fseh20180213cb2-8327-e.pdf

3. The Government of the Hong Kong Special Administrative Region. LCQ14. [Internet]. 2018. [cited 5 March 2020]. Available from:

https://gia.info.gov.hk/general/201504/29/P201504290 587_0587_145663.pdf

4. Legislative Council. Panel on Food Safety and Environmental Hygiene Promotion of Green Burial. [Internet]. 2020. [cited 5 March 2020]. Available from: https://www.legco.gov.hk/yr19-

20/english/panels/fseh/papers/fseh20200114cb2-4825-e.pdf

5. Bruni, C. Green Burial and the North-South Divide. [Internet]. 2014. [cited 3 November 2019]. Available from: https://daily.jstor.org/green-burial-and-the-northsouth-divide/

6. Spade, K. How Your Death Affects Climate Change. [Internet]. 2015. [cited 20 February 2020]. Available from: https://www.huffpost.com/entry/how-yourdeath-affects-cl_b_6263152

7. Green Burial Society of Canada. History of Green Burial. [Internet]. n.d. [cited 3 November 2019]. Available from: http://www.greenburialcanada.ca/history-of-greenburial

8. Green Burial Council. How does the GBC define green burial? [internet] [cited 17 March 2020]. Available from: 
https://www.greenburialcouncil.org/green_burial_defi ned.html

9. Funeral Consumers Alliance. Green Burial, An Environmentally Friendly Choice. [Internet]. n.d. [cited 3 November 2019]. Available from: https://funerals.org/?consumers=green-burial

10. Food and Environmental Hygiene Department. A Guide to After-Death Arrangements. [Internet]. 2019. [cited 3 November 2019]. Available from: https://www.fehd.gov.hk/english/cc/die_todo_e.pdf

11. Food and Environmental Hygiene Department. Supply of Public Niches (from 2019 to 2022). [Internet]. 2020. [cited 3 November 2019]. Available from: https://www.fehd.gov.hk/english/cc/notice_supply_of _public_niches.html

12. Food and Environmental Hygiene Department. Columbarium facilities in Hong Kong. [internet]. [cited 18 March 2020]. Available from:

https://www.legco.gov.hk/researchpublications/english/1718issh31-columbarium-facilitiesin-hong-kong-20180626-e.pdf

13. Food and Environmental Hygiene Department. Public Visit on Free Ferry Service for Scattering of Cremains at Sea. [Internet]. 2018. [cited 3 November 2019]. Available from: https://www.greenburial.gov.hk/en/scatteringcremains-sea/intro.html

14. Wong, W. The Concept of Death and the Growth of Death Awareness Among University Students in Hong Kong. OMEGA - Journal of Death and Dying. 2016; 74(3), 304-328.

15. Mjelde-Mossey, L. A., \& Chan, C. L. W. Survey on Death and Dying in Hong Kong. Social Work in Health Care. 2007; 45(1), 49-65

16. Harker, A. Landscapes of the Dead: an Argument for Conservation Burial. Berkeley Planning Journal. 2012; 25(1), 150-159.

17. National Environment Agency. Crypt Burial System. [Internet]. 2018. [cited 15 March 2020]. Available from: https://www.nea.gov.sg/our-services/afterdeath/crypt-burial-system 


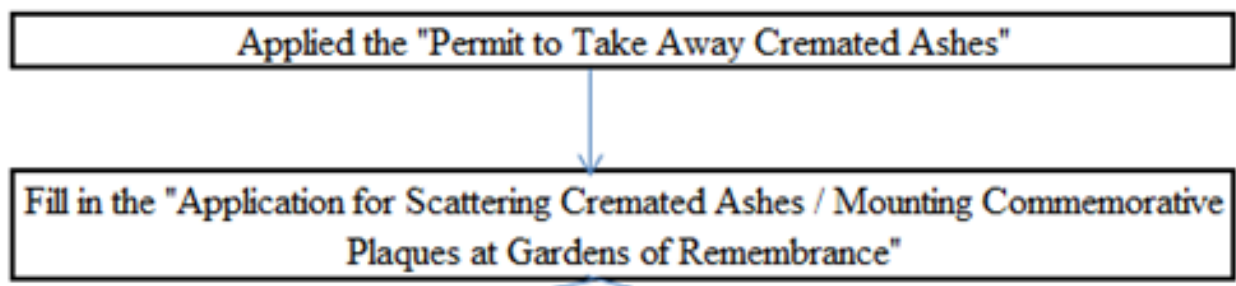

Applying scattering ashes in gardens of remembrance which are in the Islands District

Submit the application form, the original of "Permit to Take Away Cremated Ashes", the original and copy of the document issued by the relative rural committee and the original and copy of the statutory declaration to Cemeteries and Crematoria Office
Applying scattering ashes in gardens of remembrance which are not in the Islands District

Submit the application form and the original of "Permit to Take Away Cremated Ashes" to Cemeteries and Crematoria Office
Can scatter ashes at the gardens of remembrance
Cannot scatter ashes at the gardens of remembrance 


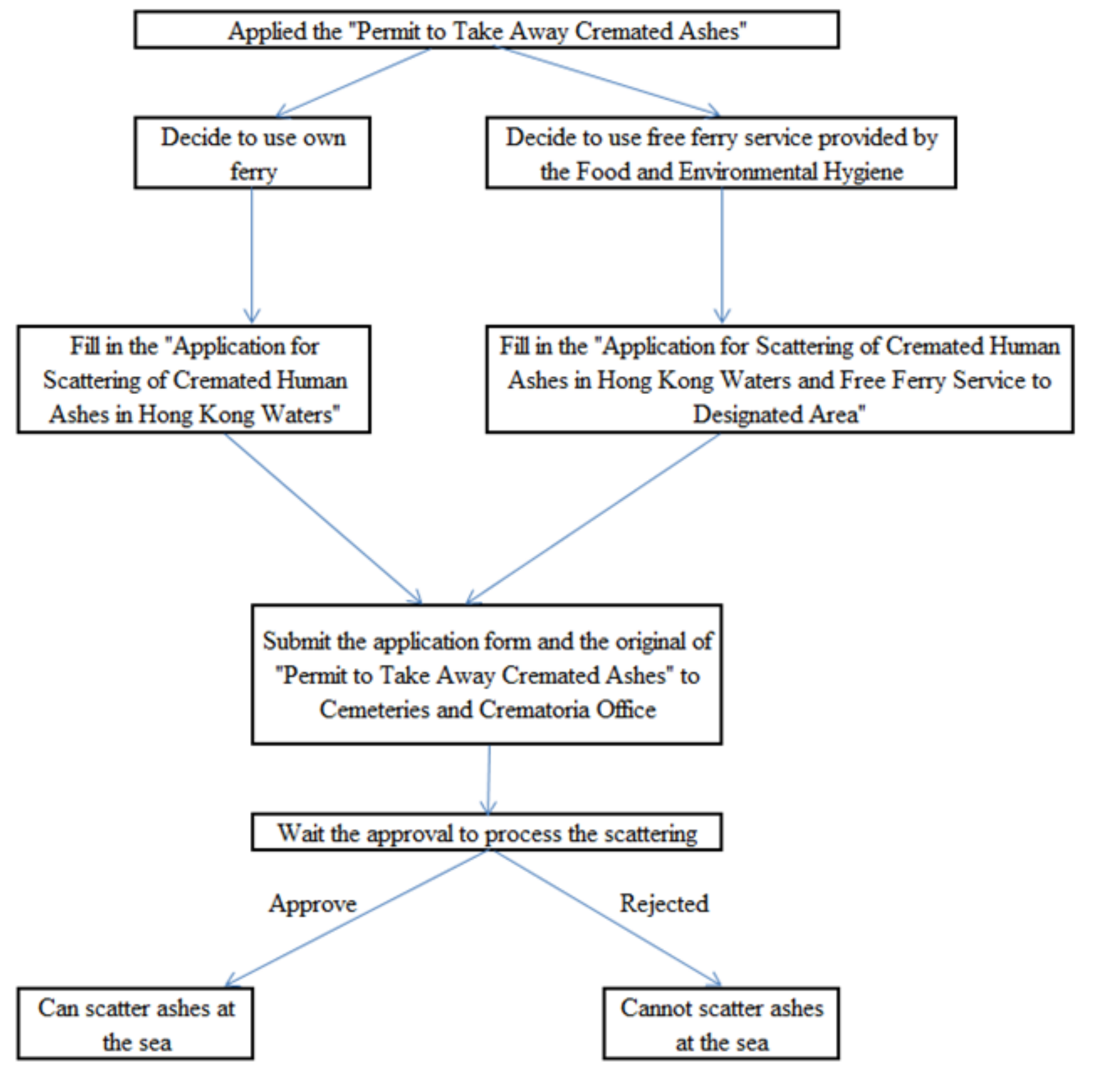

